\title{
TARGETING INTERLEUKIN 17 IN THE TREATMENT OF RHEUMATOID ARTHRITIS
}

\author{
CĂTĂLIN CODREANU ${ }^{1,2 \# *}$, CLAUDIU C. POPESCU ${ }^{1,2 \#}$, CORINA D. MOGOȘAN ${ }^{1,2 \#}$, LUMINIȚA \\ ENACHE $^{1,2 \#}$, , GINA MANDA ${ }^{3 \#}$, FLORIAN BERGHEA ${ }^{1,4}$, LAURA GROȘEANU $^{1,4}$, DENISA \\ PREDET⿱EANU ${ }^{1,4 \#}$
}

\author{
1 "Carol Davila" University of Medicine and Pharmacy, Bucharest, Romania \\ 2 "Ion Stoia" Clinical Centre for Rheumatic Diseases, Bucharest, Romania \\ 3 "Victor Babeș" National Institute for Research and Development in Pathology and Biomedical Sciences, Bucharest, Romania \\ 4 "Sfânta Maria” Clinical Hospital, Bucharest, Romania
}

*corresponding author: catalin.codreanu@reumatologiedrstoia.ro

\#Authors with equal contribution

Manuscript received: October 2017

\begin{abstract}
Interleukin 17 (IL-17) is a family of pro-inflammatory cytokines discovered in 1993. IL-17 drives an important pathogenic pathway in rheumatoid arthritis (RA), leading to and sustaining chronic inflammation. The recognition of this role made IL17 a potential therapeutic target of biological drugs. In the current study, meta-analytical data on the effect of anti-IL-17 therapy in RA revealed that secukinumab and ixekizumab were effective in generating significant responses, but brodalumab was not. In terms of safety, anti-IL-17 therapy did not significantly increase the overall risk of any side effects compared to placebo, but the analysis of individual side effects revealed an increased risk of infection. Evidence suggests that the involvement of IL-17 which can be sensitive to treatment occurs early in the disease process. This would explain the seemingly limited success of anti-IL-17 targeted therapy found by RA studies so far. Trials recruiting asymptomatic and early symptomatic RA patients are needed to confirm this hypothesis.
\end{abstract}

\section{Rezumat}

Interleukina 17 (IL-17) reprezintă o familie de citokine pro-inflamatoare descoperite în 1993. IL-17 joacă un rol important în patogenia poliartritei reumatoide (PR), prin efectul său de generare și susținere a inflamației cronice. Identificarea acestui rol a condus la țintirea IL-17 cu agenți biologici. Meta-analiza terapiei anti-IL-17 în PR a raportat că secukinumab și ixekizumab, dar nu şi brodalumab, sunt eficiente în a induce un răspuns semnificativ clinic. În ceea ce privește siguranţa tratamentului cu aceste molecule comparativ cu placebo, terapia anti-IL-17 nu a crescut riscul general de reacții adverse, însă sub-analiza pe reacții adverse individuale a evidențiat un risc crescut de infecții. Studiile sugerează că implicarea IL-17 în patogenia PR este sensibilă la terapie în fazele incipiente ale bolii. Acest fapt ar putea explica succesul relativ scăzut la terapiei anti-IL-17 în PR de până acum. Pentru confirmarea acestei ipoteze sunt necesare studii care să includă pacienți asimptomatici și pacienți cu PR precoce.

Keywords: interleukin 17 , rheumatoid arthritis, biological drugs

\section{Introduction}

The pathogenesis of chronic inflammation in rheumatoid arthritis (RA) consists of the activation of a large number of cells contributing to the immune and inflammatory responses and involvement of a cascade of pro-inflammatory cytokines such as tumour necrosis factor (TNF $\alpha)$ and interleukins (IL) [3, 63]. The understanding of this pathogenic mechanism, along with advances in biopharmaceutical technology (recombinant deoxyribonucleic acid technique), lead to the development of revolutionary drugs with more specific cellular and highly specific molecular targets. The currently approved biologic drugs for RA include anti-T cell agent abatacept, anti-B cell agent rituximab, anti-TNF $\alpha$ agents adalimumab, certolizumab, etanercept, golimumab, and infliximab, anti-IL-6 agents tocilizumab and sarilumab and anti-IL-1 agent anakinra. By targeting a specific component of the immuno-inflammatory network in RA, therefore eliminating or diminishing its pathogenic role, these drugs proved to be efficacious in controlling disease activity and achieving disease remission defined using composite indexes including joint counts, levels of acute phase reactants and patientreported outcomes. Of note, none of these drugs were able to induce disease remission in all treated patients or even low disease activity - a fact which proves the complexity of the disease process. A newcomer to the RA inflammatory network is IL-17. The recognition of its role in generating and sustaining chronic inflammation in RA suggested IL-17 as a potential therapeutic target of biological drugs. This review will briefly account IL-17 biology, examine 
its role in the pathogenesis of RA and analyse the therapeutic progress made so far by targeting IL-17 in RA.

\section{Biology aspects of IL-17}

Properties of IL-17

IL-17 was discovered in 1993 in rodent activated Tcell hybridoma [61]. It revealed high resemblance to the HVS13 herpes virus gene and therefore it has historically been known as cytotoxic T-lymphocyteassociated antigen 8 (CTLA-8) [37].

Proteomics and genomics revealed that there are six members pertaining to the IL-17 family (IL-17A-F) [41], all with different structure and low resemblance with other cytokines. The human genome is coded differently concerning the IL-17 cytokines: chromosome 6 p12 for IL-17A and IL-17F, chromosome $5 \mathrm{q} 32$ for IL-17B, chromosome 16q24 for IL-17C, chromosome 13q11 for IL-17D and chromosome 14q11 for IL-17E (currently renamed IL-25 due to its structural and functional homology with IL-17 family [19]).

The most relevant for autoimmunity and the most studied members are IL-17A and IL-17F [47] due to their marked pro-inflammatory activity. Human IL-17A is a $32 \mathrm{kDa}$ homodimeric cytokine with approximately 155 amino acids per monomer (Figure 1). IL-17A is especially expressed on epithelia and mucosa [41] and its function is to provide host immunity for microorganisms. IL-17A can also form heterodimers with IL-17F, but with less biological activity [53].

IL-17-producing cells

IL-17 is mainly produced by T helper 17 (Th17) cells, a distinct subpopulation of CD4+ T cells. However, other immune cells can contribute to the production of IL-17: natural killer cells, myeloid cells, B cells [65], memory T cells [11] and $\gamma \delta \mathrm{T}$ cells [10] can produce IL-17 when activated. Likewise, mast cells account for a significant percent of the local production of IL-17 in the synovium [29], while CD70+ CD4+ T cells contribute to the systemic production of IL-17 [54]. Even non-immune cells, like epithelial cells, can produce IL-17 [48].

Th17 differentiate from naïve CD4+ T cells in an inflammatory milieu and develop by stimulation with pro-inflammatory cytokines (transforming growth factor - TGF $\beta$, IL-1 $\beta$, IL-6, IL-21, IL-23) [35] and prostaglandin E2 (PGE2 [76]), but their development is inhibited by Th1 and Th2 cells through their specific cytokines (interferon - IFN $\gamma$, IL-4) [60]. These relatively newly discovered cells differ from Th1 and Th2 cells [25] by their cytokine production profile (IL-6, IL-17, IL-21, IL-22, IL-26, granulocyte-macrophage colony-stimulating factor - GM-CSF, TNF $\alpha$, but not IL-4 and INF $\gamma$ ) [60] and by their receptor expression profile (CC chemokine receptor 2 - CCR2, CCR4, CCR6, IL-23R, killer cell lectin-like receptor
B1 - KLRB1) [60]. The physiologic function of Th17 cells is host defence against pathogens (for example by regulation of tissue inflammation), but their involvement in autoimmunity has been well documented, including chronic inflammatory rheumatic diseases such as RA [4], spondyloarthritis [68] and psoriatic arthritis [49]. IL-17 receptors and signalling

There are five homologous receptors which bind members of the IL-17 cytokine family: IL-17RA and IL-17RC (which bind IL-17A and IL-17F), IL-17B (which binds IL-17E), IL-17D (an orphan receptor which regulates IL-17RA signalling [50]) and IL17RE (which binds IL-17C) [41]. All of these receptors are transmembrane proteins with an extracellular fibronectin III-like domain and an intracellular SEF/IL-17R (SEFIR) domain [37].

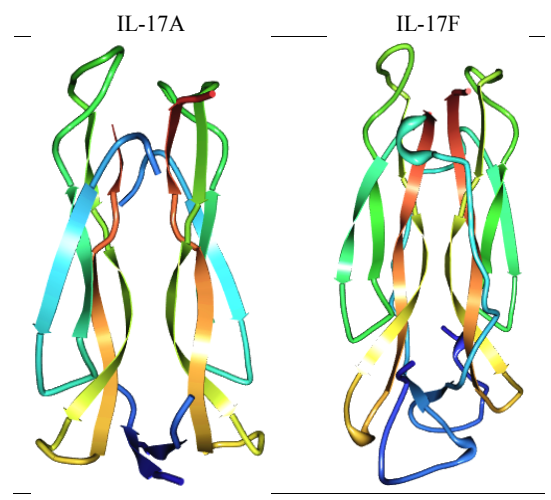

Figure 1.

Structure of human IL-17A (left; X-ray diffraction at $2.48 \AA$ resolution - PDB ID: 4HR9 [43]) and IL-17F (right; X-ray diffraction at $2.85 \AA$ resolution - PDB

ID: 1JPY [32]). IL - interleukin; PDB - protein database

IL-17RA (CD217) is a type I transmembrane glycoprotein coded on chromosome $22 \mathrm{q} 11$ and is ubiquitously expressed on somatic cells. In association with IL-17RC, IL-17RA forms a heteromeric receptor complex through which IL$17 \mathrm{~A}$ and IL-17F induce their pro-inflammatory effects [37]. The activation of pro-inflammatory genes can be a singular effect of IL-17A/F signalling or can occur in synergy, or additively, with other pro-inflammatory cytokines (for example TNF $\alpha$ ) [62]. Another effect of IL-17 signalling is the stabilization of messenger ribonucleic acid (mRNA) coding pro-inflammatory proteins [72]: mRNA molecules are protected from degradation and therefore are available for more protein synthesis. These effects (induction of proinflammatory genes and mRNA stabilization) are mediated through the adaptor protein Act1 [59] and tumour necrosis factor receptor associated factors (TRAF; [26]; Figure 2). 


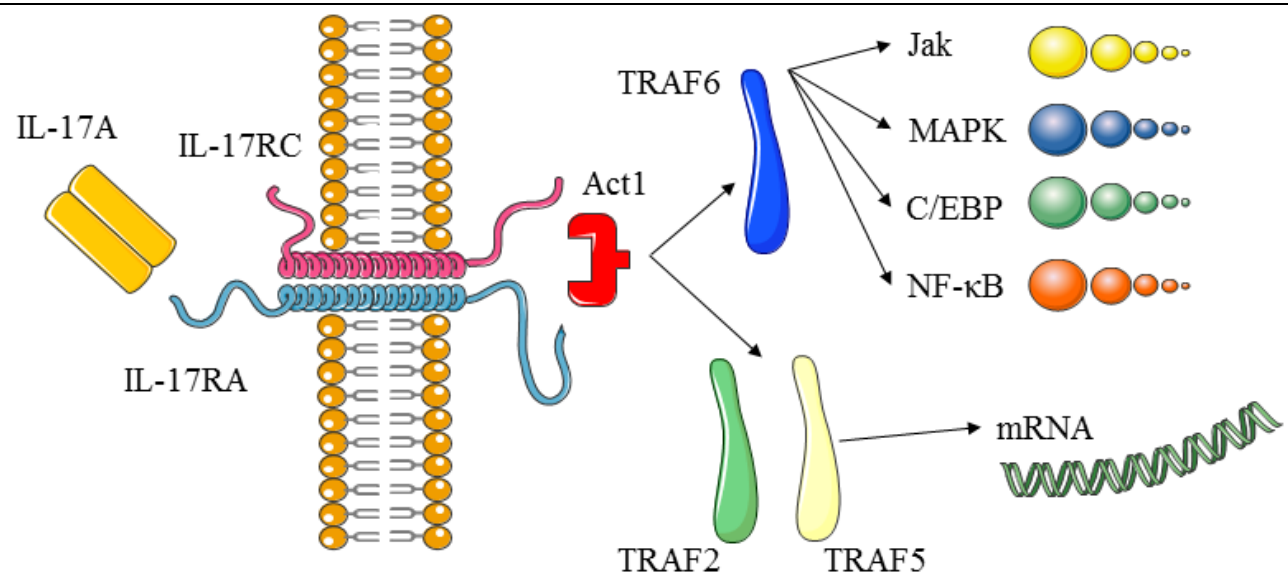

Figure 2.

IL-17A signalling through the IL-17RA/IL-17RC heteromeric receptor complex and activation of intracellular pathways [28, 37, 63, 78]: NK- $\kappa \mathrm{B}, \mathrm{C} / \mathrm{EBP}, \mathrm{MAPK}$ and JAK (JAK-STAT, JAK PI3K). Image created using Servier Medical Art. Abbreviations: C/EBP - CCAAT-enhancer-binding protein; IL - interleukin; Jak - Janus kinase; MAPK - mitogen-activated protein kinase; mRNA - messenger ribonucleic acid; NF- $\mathrm{B}$ - nuclear factor kappa-light-chain-enhancer of activated B cells; STAT - Signal Transducer and Activator of Transcription;

TRAF - tumour necrosis factor receptor associated factor.

\section{Th17 cells and IL-17 in RA}

Th17 cells and IL-17 in the pathogenesis of RA IL-17 seems to be involved in all stages of RA, from genetic predisposition to its structural hallmark endpoint of joint erosion. Recent metaanalyses revealed that polymorphisms of IL-17 genes are associated with RA susceptibility [39]. Other studies report similar findings in different populations: Polish carriers of rs763780 IL-17F polymorphism have a higher risk for RA [8]; Chinese carriers of IL17A rs3819025 and rs8193036 alleles have an increased risk of RA [67]; similarly, North-African [46] and Hispanic [20] carriers of IL-17 polymorphisms have a higher risk of RA. An interesting observation on the genetic risk for RA was made by Leipe et al [40], who reported that a polymorphism of the IL-4 receptor (rs1805010) on Th17 precursors leads to an expanded Th17 population and is associated with poor clinical outcome. This observation proves the importance of Th17 cells and their cytokines in the pathogenic process of RA.

If the complex genetic risk manifests pathogenically, the patients begin to develop RA features, like autoantibodies, even before the onset of clinical arthritis. This supposedly long pathogenic process may also involve Th17 cells and IL-17 production. Observational studies have reported high numbers of peripheral Th17 cells in treatment-naïve patients with early RA [74], with increased fractions of these cells being detected in their synovium and synovial fluid [56]. As fundamental research suggests, circulating Th17 cells are infiltrating RA synovial membranes by a process of chemotaxis involving their CCR6 and C$\mathrm{C}$ motif ligand 20 (CCL20) produced by fibroblast- like synoviocytes (FSC) [27]. These Th17 cells can be stimulated to produce IL-17 by local proinflammatory cytokines, such as TNF $\alpha$ and TNFrelated weak inducer of apoptosis (TWEAK) [55]. The transcriptional activation of the IL-17 gene is possibly stimulated by epigenetic modifications of IL-17 locus (histone H3 acetylation, Lys-4 trimethylation) induced by Th17 differentiation regulators, such as transcription factor 1 (TCF-1) [6]. Observational studies have consistently reported that RA patients have higher levels of serum and synovial fluid IL-17 compared to normal subjects [58] and osteoarthritis patients [38], findings which were confirmed by a recent metaanalysis of 14 studies comparing levels of IL17 in 3118 RA patients and 2725 controls [39]. These reports place Th17 cells and IL-17 in the primary target site of RA pathogenesis and offer the first proof of a causal relationship between Th17/IL-17 system and RA. Other studies further observed significant quantitative and qualitative Th17/IL-17 associations with RA variables. There are numerous reports that both in early untreated RA and in established RA the presence of Th17 cells [51] and serum and synovial fluid levels of IL-17 correlate with acute phase reactants, auto-antibodies, disease activity score (DAS28) [58], disease severity (structural damage) [48], disease duration [42] and even RA-related anxiety and depression [44].

After its involvement in the early stages of disease development, IL-17 stimulates chronic synovial inflammation [6] by acting at a cellular level in all of the active joint components (synovium, blood vessels, cartilage, bone) with additive effect to other pro-inflammatory cytokines (Table I). This IL-17-sustained chronic inflammation translates 
FARMACIA, 2018, Vol. 66, 3

clinically in persistent arthritis, which eventually leads to irreversible tissue damage. Most of the modern clinical management of RA patients aims to prevent the formation of bone erosions and to slow down their progression, since they are associated with irreversible joint damage and a low quality of life. At this end of the pathological process in RA, IL-17 plays an important role in regulating the activity of osteoclasts (the cellular mediators of joint erosions). IL-17 stimulates osteoclastogenesis from monocytes [34] via the receptor activator of nuclear factor $\kappa-B$ ligand (RANKL) [64] and upregulates RANKL expression on FLS from RA joints [33], leading eventually to the characteristic histopathological RA bone erosion [12].

Table I

The biological effects of IL-17 on FLS, vascular, immune and bone cells

\begin{tabular}{cccc}
\hline effect & target & process & ref. \\
\hline$\uparrow$ & MMP1-3, MMP9, MMP13 & tissue destruction & {$[1,47,48,60]$} \\
$\uparrow$ & TNFa & inflammation & {$[1,47,48]$} \\
$\uparrow$ & IL-1, IL-6, IL-8, IL-10, IL-12 & inflammation & {$[1,16,47,48,60]$} \\
$\uparrow$ & PGE 2 & inflammation & {$[11,35,69,70]$} \\
$\uparrow$ & GM CSF & inflammation & {$[6,11,45,48]$} \\
$\uparrow$ & osteoclasts & bone destruction & {$[12,47,48]$} \\
$\downarrow$ & osteoblasts & bone formation & {$[12]$} \\
$\downarrow$ & cartilage progenitor cells & cartilage repair & {$[66]$} \\
$\uparrow$ & CXCL1, CXCL2, CXCL5, CXCL12 & lymphocyte infiltration & {$[6,16,47]$} \\
$\uparrow$ & CXCL8 & chemotaxis, angiogenesis & {$[6,45,48]$} \\
$\uparrow$ & CCL2, CCL3, CCL5, CCL20 & chemotaxis & {$[6,45,48]$} \\
$\uparrow$ & VEGF & angiogenesis & {$[47,48,60]$} \\
$\uparrow$ & COX-2 & inflammation & {$[16,69,70]$} \\
$\uparrow$ & TLR2, TLR3, TLR4, TLR9 & autoimmunity & {$[6,38]$} \\
$\uparrow$ & FLS, T and B cells, granulocytes & survival (anti-apoptotic) & {$[16,48]$} \\
$\uparrow$ & NO production & inflammation & {$[6,16]$} \\
$\uparrow$ & ICAM1 & lymphocyte infiltration & {$[2]$} \\
$\downarrow$ & miR-23b (mRNA) & IL-17 suppression & {$[77]$} \\
\hline
\end{tabular}

CCL - chemokine (C-C motif) ligand; COX - cyclooxygenase; CXCL - C-X-C motif chemokine ligand; ICAM - intercellular adhesion molecule; IL - interleukin; FLS - fibroblast-like synovial cells; GM CSF - granulocyte-macrophage colony-stimulating factor; MMP - matrix metalloproteinase; mRNA - messenger ribonucleic acid; NO - nitric oxide; PG - prostaglandin; TLR - toll-like receptor; VEGF - vascular endothelial growth factor.

Since IL-17 seems to play a key role in the pathogenesis of RA and animal models of induced arthritis [35] showed promising results when interfering with this cytokine, IL-17 became a viable therapeutic target [75]. A meta-analysis from 2016 by Kunwar et al. [36] aggregated seven double-blind placebocontrolled randomized clinical trials (RCT) of anti-IL17 therapy (brodalumab, ixekizumab and secukinumab) in 1226 patients with active RA (905 patients on anti-IL-17 agents and 321 patients on placebo). In terms of treatment response compared to placebo, anti-IL-17 agents generally had a significantly higher efficacy in achieving American College of Rheumatology 20 (ACR20) and ACR50, but not ACR70 response. The efficacy analysis on individual molecules revealed that secukinumab and ixekizumab were effective in generating ACR20 responses, but brodalumab was not. In terms of safety, anti-IL-17 therapy did not significantly increase the overall risk of any side effects compared to placebo, but the analysis of individual side effects revealed an increased risk of infection.

Secukinumab

Secukinumab is a recombinant fully human monoclonal IgG1 $\kappa$ antibody designed to bind to IL-17A, neutralizing its pro-inflammatory effects. The drug is currently approved for the treatment of plaque psoriasis, psoriatic arthritis and ankylosing spondylitis. Secukinumab has a good safety profile, the most frequent adverse reactions being upper respiratory tract infections, oral herpes and diarrhoea which most often resolve with symptomatic treatment.

There are several published randomised controlled trials (RCTs) of secukinumab treatment in RA [36] that show mixed results in terms of efficacy endpoints, such as ACR20 response at 3-6 months (Table II). At present, there are also three RCTs of secukinumab in RA under way (NCT01770379 [14], terminated early for non-safety reasons, NCT01377012 [13] and NCT01901900 [15]), but the available results from the first two studies revealed a similar pattern.

\section{Ixekizumab}

Ixekizumab is a humanized IgG4 monoclonal antibody that binds to IL-17A and it is approved for the treatment of plaque psoriasis. Clinical trials have revealed that it has a good safety profile and that the most common side effects include upper respiratory tract infections, tinea infections, oropharyngeal pain, nausea and injection site reactions.

A phase II RCT with different doses of ixekizumab, administered subcutaneously at $0,1,2,4,6,8$ and 10 
FARMACIA, 2018, Vol. 66, 3

weeks, was carried out on 260 biologic-naïve and 188 anti-TNF $\alpha$-failure RA patients using ACR20 at 3 months as the primary outcome [24]. The proportion of patients achieving the primary endpoint under ixekizumab was double, compared to placebo in the $30 \mathrm{mg}$ biologic-naïve group and in the $80 \mathrm{mg}$ antiTNF $\alpha$-failure group $(\mathrm{p}<0.05)$. Only the highest dose regime of ixekizumab (180 mg) achieved a significantly higher proportion of patients in DAS28 remission and low disease activity compared to placebo after 3 months of treatment.

A total of 201 biologic-naïve and 99 anti-TNF $\alpha$ failure RA patients completed the double blind phase of the trial and entered in the open label phase [21]. There were no additional safety concerns, the responders from the double blind phase maintained their benefit after one year of treatment and the proportion of former placebo recipients achieving ACR20-70 responses was similar to the original double blind phase. The authors concluded that phase III trials of ixekizumab in RA are warranted.

\section{Brodalumab}

Brodalumab is a fully human monoclonal IgG2 antibody designed to bind to IL-17RA in order to prevent IL-17 pro-inflammatory signalling. It is currently approved for the treatment of plaque psoriasis and its most common side effects include influenza, tinea infections, neutropenia, headache, gastrointestinal manifestations, fatigue and musculoskeletal symptoms.

A single RCT with three doses of brodalumab was carried out on 252 methotrexate- failure RA patients [57]. The proportion of patients achieving ACR20-70 responses after 3 months with brodalumab was not significantly different compared to placebo. The study did not raise any specific safety concerns.

\section{Discussion}

The first question and the most relevant is whether IL-17 therapy is efficacious in treating active RA. According to the only meta-analysis available [36], anti-IL-17A agents can induce meaningful treatment ACR-defined responses compared to placebo. There are controversies regarding this observation, namely the existence of negative results reported by the secukinumab RCTs (Table II) and the general low magnitude of the induced clinical response with anti-IL-17A agents. A certain amount of variation is anticipated in RCTs with different study designs and different study populations in terms of age, gender distribution, disease duration, disease severity, prognostic factors (e.g., serology, baseline acute phase reactants, radiographic scores) and treatment history (treatmentnaïve, methotrexate-failure, anti-TNF $\alpha$-failure). Is this variation enough to justify negative results of secukinumab? Since anti-TNF $\alpha$ agents consistently register better results than placebo and methotrexate irrespective of treatment history [18], this seems improbable. Given that anti-IL-17A agents display a certain/high degree of efficacy, it must be that there is a specific clinical and/or biochemical profile of antiIL-17A responders which remains to be defined. The identification of biomarkers for the treatment outcome in RA patients is warranted and it seems that these should not exclude anti-IL-17A therapy [17]. Given that the results have shown that IL-17 contributes to RA pathogenesis from the observable start/onset of the disease, it is reasonable to hypothesis that the earlier the treatment is initiated, the better the treatment results. Therefore, exploratory studies with anti-IL-17A treatment of patients in preclinical stages (arthralgia due to possible progression to RA, asymptomatic auto-immunity) and early clinical stages (early RA, disease duration less than $6-12$ months) are warranted. Even if these studies confirm the existing evidence, anti-IL-17A agents remain useful in selected patients in clinical practice (for example patients with chronic heart failure, multiple biological drug failure, allergy, history of cancer, history of tuberculosis or viral hepatitis etc.) for whom currently approved therapies are not appropriate.

The second question and the most intriguing one concerns the observations registered after IL-17 inhibition with regards to the implications for the pathogenesis of RA. Since IL-17A inhibitors, secukinumab and ixekizumab, displayed efficacy in treating active RA, while the IL-17RA inhibitor brodalumab did not, it seems that the biology and pathology of Th17/IL-17 activity is far more complex than anticipated. There are at least three possible explanations for this observation: the causal pathogenic mechanism of RA may compensate for the loss of IL-17 activity using other cytokines, it may activate IL-17R using ligands different from IL-17 family members, or it may induce the same proinflammatory effects of IL-17 by signalling through different receptors. Fundamental research is essential and animal experimental combinations of anticytokine agents (for example anti-TNF $\alpha$ and antiIL-17) could be a relevant method in order to elucidate further RA pathogenesis. A soluble IL-17A receptor, similar to the concept of etanercept, might be more effective than the available anti-IL-17 agents. Even though anti-IL-17A agents were effective in treating active RA, the size of the effect was lower than the anticipated efficacy based on theory and preclinical tests. The relevance of this observation for the pathogenesis of RA can be explained either by the pleiotropism of IL-17 biologic effects ([48]; Table I; IL-17 influences processes like immune cell migration and angiogenesis that are driven by other significant chemical mediators) or by the fact that IL-17 is not as important to RA as previously thought. 
Table II

Phase II-III RCT of secukinumab treatment in active RA

\begin{tabular}{|c|c|c|c|c|c|}
\hline study & $n^{\circ}$ & $R A$ & primary endpoint & arms & result \\
\hline $\begin{array}{l}\text { Blanco et al } \\
\text { [7] (2017) }\end{array}$ & 551 & anti-TNF $\alpha$ failure & ACR20 at 6 months & $\begin{array}{l}\text { placebo } \\
\text { secukinumab } 150 \mathrm{mg} \\
\text { secukinumab } 75 \mathrm{mg} \\
\text { abatacept }\end{array}$ & $\begin{array}{l}18.1 \% \\
30.7 \%{ }^{\#} \\
28.3 \% \\
42.8 \%{ }^{\#}\end{array}$ \\
\hline $\begin{array}{l}\text { Burmester et al } \\
\text { [9] (2016) }\end{array}$ & 100 & treatment-naïve & $\begin{array}{l}\triangle \mathrm{DAS} 28 \text { at } 3 \text { months } \\
\text { ACR20 at } 3 \text { months }\end{array}$ & $\begin{array}{l}\text { placebo } \\
\text { secukinumab } 10 \mathrm{mg} / \mathrm{kg}\end{array}$ & $\begin{array}{l}-0.71 / 25.0 \% \\
-2.41^{\#} / 85.1 \%{ }^{\#}\end{array}$ \\
\hline $\begin{array}{l}\text { Tlustochowicz et al. } \\
\text { [73] (2016) }\end{array}$ & 221 & MTX-nonresponders & ACR20 at 3 months & $\begin{array}{l}\text { placebo } \\
\text { secukinumab } 150 \mathrm{mg}\end{array}$ & $\begin{array}{l}40.9 \% \\
49.2 \%\end{array}$ \\
\hline $\begin{array}{l}\text { Genovese } \text { et al } \\
{[23](2013 ; \text { see also }} \\
[22,71])\end{array}$ & 237 & MTX-nonresponders & ACR20 at 4 months & $\begin{array}{l}\text { placebo } \\
\text { secukinumab } 25 \mathrm{mg} \\
\text { secukinumab } 75 \mathrm{mg} \\
\text { secukinumab } 150 \mathrm{mg} \\
\text { secukinumab } 300 \mathrm{mg}\end{array}$ & $\begin{array}{l}34 \% \\
36.0 \% \\
46.9 \% \\
46.5 \% \\
53.7 \%\end{array}$ \\
\hline $\begin{array}{l}\text { Hueber } \text { et al } \\
{[30](2010)}\end{array}$ & 52 & MTX-nonresponders & ACR20 at 6 weeks & $\begin{array}{l}\text { placebo } \\
\text { secukinumab } 10 \mathrm{mg} / \mathrm{kg}\end{array}$ & $\begin{array}{l}27 \% \\
46 \%\end{array}$ \\
\hline $\begin{array}{l}\text { NCT01770379 } \\
(\text { see }[14])\end{array}$ & 242 & anti-TNF $\alpha$ failure & ACR20 at 6 months & $\begin{array}{l}\text { placebo } \\
\text { secukinumab } 75 \mathrm{mg} \\
\text { secukinumab } 150 \mathrm{mg}\end{array}$ & $\begin{array}{l}27.2 \% \\
37.5 \% \\
38.3 \%\end{array}$ \\
\hline $\begin{array}{l}\text { NCT01377012 } \\
(\text { see [13]) }\end{array}$ & 637 & anti-TNF $\alpha$ failure & ACR20 at 6 months & $\begin{array}{l}\text { placebo } \\
\text { secukinumab } 10 \mathrm{mg} / \mathrm{kg}-75 \mathrm{mg} \\
\text { secukinumab } 10 \mathrm{mg} / \mathrm{kg}-150 \mathrm{mg}\end{array}$ & $\begin{array}{l}19.6 \% \\
35.2 \%{ }^{\#} \\
35.2 \%\end{array}$ \\
\hline
\end{tabular}

Significant differences ( $\mathrm{p}$ value bellow the chosen threshold: $\mathrm{p}<0.02$ for the Hueber et al study and $\mathrm{p}<0.05$ for the rest) between placebo and active drug arms are marked with "\#”. ACR - American College of Rheumatology; DAS - disease activity score; MTX - methotrexate; $\mathrm{RA}$ - rheumatoid arthritis; RCT - randomized clinical trial; TNF - tumour necrosis factor.

Both of these hypotheses are supported by the therapeutic behaviour of IL-17 inhibition in other disease phenotypes. Anti-IL-17A agents secukinumab and ixekizumab and IL-17RA inhibitor brodalumab were effective for psoriasis and psoriatic arthritis [49] and secukinumab was effective for ankylosing spondylitis [5]. However, safety reports from these RCTs revealed the risk of Crohn's disease exacerbation, knowing the IL-17 is a significant pathogenic factor in this disease [52], a paradoxical effect which was also demonstrated in controlled trials [31]. It seems that the involvement of the Th17/IL-17 system in RA and Crohn's disease compared to its involvement in psoriasis, psoriatic arthritis and ankylosing spondylitis is either completely different or is supported by different (combinations of) pathogenic factors which remain to be explained. Since Crohn's disease is more frequently associated with spondyloarthritis than with RA and since all these diseases respond well to anti-TNF $\alpha$ agents, it is possible that the crucial role of the Th17/IL-17 system in RA is related to increasing the risk of the disease and to initiating inflammation and targeting synovia, its role becoming less and less preeminent as the chronic pathogenic process unfolds.

\section{Conclusions}

The newly discovered Th17/IL-17 system undoubtedly drives an important pathogenic pathway leading to and sustaining chronic inflammation in RA. Evidence suggests that the treatment-sensitive involvement of Th17/IL-17 system occurs early in the disease process.
This would explain the seemingly low success of anti-IL-17 targeted therapy in RA studies so far. RCTs designed to include asymptomatic and early symptomatic RA patients are needed to confirm this hypothesis.

\section{References}

1. Agarwal S, Misra R, Aggarwal A, Interleukin 17 levels are increased in juvenile idiopathic arthritis synovial fluid and induce synovial fibroblasts to produce proinflammatory cytokines and matrix metalloproteinases. The Journal of rheumatology, 2008; 35(3): 515-519.

2. Albanesi C, Cavani A, Girolomoni G, IL-17 is produced by nickel-specific $\mathrm{T}$ lymphocytes and regulates ICAM-1 expression and chemokine production in human keratinocytes: synergistic or antagonist effects with IFN-gamma and TNF-alpha. Journal of immunology, 1999; 162(1): 494-502.

3. Angelotti F, Parma A, Cafaro G, Capecchi R, Alunno A, Puxeddu I, One year in review 2017: pathogenesis of rheumatoid arthritis. Clin Exp Rheumatol, 2017; 35(3): 368-378.

4. Bârcă M, Manda $G$, Ciobanu AM, Bălălău C, Lupuleasa D, Burcea Dragomiroiu GTA, Pop A, Popa DE, Baconi DL, Immunomodulatory effects of methadone following methotrexate therapy in a rat model of arthritis. Farmacia, 2017; 65(3): 423-428.

5. Baraliakos X, Kivitz AJ, Deodhar AA, Braun J, Wei JC, Delicha EM, Talloczy Z, Porter B, Group MS, Long-term effects of interleukin-17A inhibition with secukinumab in active ankylosing spondylitis: 3 -year efficacy and safety results from an extension 
FARMACIA, 2018, Vol. 66, 3

of the Phase 3 MEASURE 1 trial. Clin Exp Rheumatol, 2018; 36(1): 50-55.

6. Benedetti G, Miossec P, Interleukin 17 contributes to the chronicity of inflammatory diseases such as rheumatoid arthritis. Eur J Immunology, 2014; 44(2): 339-347.

7. Blanco FJ, Moricke R, Dokoupilova E, Codding C, Neal J, Andersson M, Rohrer S, Richards H: Secukinumab in active rheumatoid arthritis: a phase III randomized, double-blind, active comparatorand placebo-controlled study. Arthritis \& rheumatology, 2017; 69(6): 1144-1153.

8. Bogunia-Kubik $\mathrm{K}$, Swierkot J, Malak A, Wysoczanska B, Nowak B, Bialowas K, Gebura K, Korman L, Wiland P, IL-17A, IL-17F and IL-23R Gene Polymorphisms in Polish Patients with Rheumatoid Arthritis. Archivum immunologiae et therapiae experimentalis, 2015; 63(3): 215-221.

9. Burmester GR, Durez P, Shestakova G, Genovese MC, Schulze-Koops H, Li Y, Wang YA, Lewitzky S, Koroleva I, Berneis AA, Association of HLADRB1 alleles with clinical responses to the antiinterleukin-17A monoclonal antibody secukinumab in active rheumatoid arthritis. Rheumatology, 2016; 55(1): 49-55.

10. Caccamo N, La Mendola C, Orlando V, Meraviglia S, Todaro M, Stassi G, Sireci G, Fournie JJ, Dieli F, Differentiation, phenotype, and function of interleukin-17-producing human Vgamma9Vdelta2 T cells. Blood, 2011; 118(1): 129-138.

11. Chabaud M, Durand JM, Buchs N, Fossiez F, Page G, Frappart L, Miossec P, Human interleukin-17: A T cell-derived proinflammatory cytokine produced by the rheumatoid synovium. Arthritis and Rheumatism, 1999; 42(5): 963-970.

12. Chabaud M, Lubberts E, Joosten L, van Den Berg W, Miossec P, IL-17 derived from juxta-articular bone and synovium contributes to joint degradation in rheumatoid arthritis. Arthritis research, 2001; 3(3): 168-177.

13. ClinicalTrials.gov Bethesda (MD) National Library of Medicine US: NCT01377012 - Efficacy at 24 weeks and safety, tolerability and long term efficacy up to 2 years of secukinumab (ain457) in patients with active rheumatoid arthritis and an inadequate response to anti-TNF $\alpha$ agents. www.ClinicalTrials.gov.

14. ClinicalTrials.gov Bethesda (MD) National Library of Medicine US: NCT01770379 - Secukinumab Efficacy and safety study in patients with rheumatoid arthritis and inadequate response to anti-TNF $\alpha$ agents. www.ClinicalTrials.gov.

15. ClinicalTrials.gov Bethesda (MD) National Library of Medicine US: NCT01901900 - safety and efficacy of extended treatment with secukinumab in anti-TNF Inadequate responders in RA. www.ClinicalTrials.gov.

16. Dembic Z, IL-17. In: The cytokines of the immune system. Elsevier Inc.; 2015: 200-202.

17. Durez $P$, Is There a future for interleukin 17 Blocking agents in rheumatoid arthritis? The Journal of rheumatology, 2016; 43(3): 465-467.

18. Fleischmann R, Tongbram V, van Vollenhoven R, Tang DH, Chung J, Collier D, Urs S, Ndirangu K, Wells G, Pope J, Systematic review and network meta-analysis of the efficacy and safety of tumour necrosis factor inhibitor-methotrexate combination therapy versus triple therapy in rheumatoid arthritis. RMD Open, 2017; 3(1): 1-15.

19. Gaffen SL, Recent advances in the IL-17 cytokine family. Current opinion in immunology, 2011; 23(5): 613-619.

20. Garcia de la Pena M, Mendez Cruz R, Garrido Guerrero E, Galicia Lopez A, Pozo Molina G, Herrera Gonzalez NE, Polymorphism rs2275913 of Interleukin-17A is related to more intensive therapy with disease-modifying anti rheumatic drugs in Mexican patients with Rheumatoid Arthritis. Acta reumatologica portuguesa, 2017; 42(2): 155-161.

21. Genovese MC, Braun DK, Erickson JS, Berclaz PY, Banerjee S, Heffernan MP, Carlier H, Safety and efficacy of open-label subcutaneous ixekizumab treatment for 48 weeks in a phase ii study in biologic-naive and TNF-IR patients with rheumatoid arthritis. The Journal of rheumatology, 2016; 43(2): 289-297.

22. Genovese MC, Durez P, Richards HB, Supronik J, Dokoupilova E, Aelion JA, Lee SH, Codding CE, Kellner H, Ikawa T, One-year efficacy and safety results of secukinumab in patients with rheumatoid arthritis: phase II, dose-finding, double-blind, randomized, placebo-controlled study. The Journal of rheumatology, 2014; 41(3): 414-421.

23. Genovese MC, Durez P, Richards HB, Supronik J, Dokoupilova E, Mazurov V, Aelion JA, Lee SH, Codding CE, Kellner H, Efficacy and safety of secukinumab in patients with rheumatoid arthritis: a phase II, dose-finding, double-blind, randomised, placebo controlled study. Annals of the rheumatic diseases, 2013; 72(6): 863-869.

24. Genovese MC, Greenwald M, Cho CS, Berman A, Jin L, Cameron GS, Benichou O, Xie L, Braun D, Berclaz PY, A phase II randomized study of subcutaneous ixekizumab, an anti-interleukin-17 monoclonal antibody, in rheumatoid arthritis patients who were naive to biologic agents or had an inadequate response to tumor necrosis factor inhibitors. Arthritis \& rheumatology, 2014; 66(7): 1693-1704.

25. Harrington LE, Hatton RD, Mangan PR, Turner H, Murphy TL, Murphy KM, Weaver CT, Interleukin 17-producing CD4+ effector T cells develop via a lineage distinct from the $\mathrm{T}$ helper type 1 and 2 lineages. Nature immunology 2005; 6(11): 1123-1132.

26. Hartupee J, Liu C, Novotny M, Sun D, Li X, Hamilton TA, IL-17 signaling for mRNA stabilization does not require TNF receptor-associated factor 6. Journal of immunology, 2009; 182(3): 1660-1666.

27. Hirota K, Yoshitomi H, Hashimoto M, Maeda S, Teradaira S, Sugimoto N, Yamaguchi T, Nomura T, Ito H, Nakamura T, Preferential recruitment of CCR6-expressing Th17 cells to inflamed joints via CCL20 in rheumatoid arthritis and its animal model. $J$ Exp Medicine, 2007; 204(12): 2803-2812.

28. Huang F, Kao CY, Wachi S, Thai P, Ryu J, Wu R, Requirement for both JAK-mediated PI3K signaling and ACT1/TRAF6/TAK1-dependent NF-kappaB activation by IL-17A in enhancing cytokine expression in human airway epithelial cells. J Immunology, 2007; 179(10): 6504-6513. 
FARMACIA, 2018, Vol. 66, 3

29. Hueber AJ, Asquith DL, Miller AM, Reilly J, Kerr S, Leipe J, Melendez AJ, McInnes IB, Mast cells express IL-17A in rheumatoid arthritis synovium. Journal of immunology, 2010; 184(7): 3336-3340.

30. Hueber W, Patel DD, Dryja T, Wright AM, Koroleva I, Bruin G, Antoni C, Draelos Z, Gold MH, Psoriasis Study G, Effects of AIN457, a fully human antibody to interleukin-17A, on psoriasis, rheumatoid arthritis, and uveitis. Science translational medicine, 2010; 2(52): 1-11.

31. Hueber W, Sands BE, Lewitzky S, Reinisch W, Higgins PD, Wehkamp J, Feagan BG, Yao MD, Karczewski $\mathrm{M}$, Secukinumab, a human anti-IL-17A monoclonal antibody, for moderate to severe Crohn's disease: unexpected results of a randomised, double-blind placebo-controlled trial. Gut, 2012; 61(12): 1693-1700.

32. Hymowitz SG, Filvaroff EH, Yin JP, Lee J, Cai L, Risser P, Maruoka M, Mao W, Foster J, Kelley RF, IL-17s adopt a cystine knot fold: structure and activity of a novel cytokine, IL-17F, and implications for receptor binding. The EMBO journal, 2001; 20(19): 5332-5341.

33. Kim KW, Kim HR, Kim BM, Cho ML, Lee SH, Th17 cytokines regulate osteoclastogenesis in rheumatoid arthritis. The American journal of pathology, 2015; 185(11): 3011-3024.

34. Kotake S, Udagawa N, Takahashi N, Matsuzaki K, Itoh $\mathrm{K}$, Ishiyama S, Saito S, Inoue K, Kamatani N, Gillespie MT, IL-17 in synovial fluids from patients with rheumatoid arthritis is a potent stimulator of osteoclastogenesis. The Journal of clinical investigation, 1999; 103(9): 1345-1352.

35. Kugyelka R, Kohl Z, Olasz K, Mikecz K, Rauch TA, Glant TT, Boldizsar F, Enigma of IL-17 and Th17 cells in rheumatoid arthritis and in autoimmune animal models of arthritis. Mediators of inflammation, 2016; 2016: 1-11.

36. Kunwar S, Dahal K, Sharma S, Anti-IL-17 therapy in treatment of rheumatoid arthritis: a systematic literature review and meta-analysis of randomized controlled trials. Rheumatology international, 2016; 36(8): 1065-1075.

37. Kuwabara T, Ishikawa F, Kondo M, Kakiuchi T, The role of IL-17 and related cytokines in inflammatory autoimmune diseases. Mediators of inflammation, 2017; 2017: 1-11.

38. Lee SY, Yoon BY, Kim JI, Heo YM, Woo YJ, Park $\mathrm{SH}$, Kim HY, Kim SI, Cho ML, Interleukin-17 increases the expression of Toll-like receptor 3 via the STAT3 pathway in rheumatoid arthritis fibroblast-like synoviocytes. Immunology, 2014; 141(3): 353-361.

39. Lee $\mathrm{YH}, \mathrm{Bae} \mathrm{SC}$, Associations between circulating IL-17 levels and rheumatoid arthritis and between IL-17 gene polymorphisms and disease susceptibility: a meta-analysis. Postgraduate medical journal, 2017; 93(1102): 465-471.

40. Leipe J, Schramm MA, Prots I, Schulze-Koops H, Skapenko A, Increased Th17 cell frequency and poor clinical outcome in rheumatoid arthritis are associated with a genetic variant in the IL4R gene, rs1805010. Arthritis \& rheumatology, 2014; 66(5): $1165-1175$.
41. Li D, Guo B, Wu H, Tan L, Chang C, Lu Q: Interleukin-17 in systemic 1upus erythematosus: A comprehensive review. Autoimmunity, 2015; 48(6): 353-361.

42. Li N, Wang JC, Liang TH, Zhu MH, Wang JY, Fu XL, Zhou JR, Zheng SG, Chan P, Han J, Pathologic finding of increased expression of interleukin-17 in the synovial tissue of rheumatoid arthritis patients. International journal of clinical and experimental pathology, 2013; 6(7): 1375-1379.

43. Liu S, Song X, Chrunyk BA, Shanker S, Hoth LR, Marr ES, Griffor MC, Crystal structures of interleukin $17 \mathrm{~A}$ and its complex with IL-17 receptor A. Nature communications, 2013; 4:1-9.

44. Liu Y, Ho RC, Mak A, The role of interleukin (IL)17 in anxiety and depression of patients with rheumatoid arthritis. International journal of rheumatic diseases, 2012; 15(2): 183-187.

45. Lubberts E; Th17 cytokines and arthritis. Seminars in immunopathology, 2010; 32(1): 43-53.

46. Marwa OS, Kalthoum T, Wajih K, Kamel H, Association of IL17A and IL17F genes with rheumatoid arthritis disease and the impact of genetic polymorphisms on response to treatment. Immunology letters, 2017; 183: 24-36.

47. Mateen S, Zafar A, Moin S, Khan AQ, Zubair S, Understanding the role of cytokines in the pathogenesis of rheumatoid arthritis. Clinica chimica acta; International journal of clinical chemistry, 2016; 455: 161-171.

48. McInnes IB, Buckley CD, Isaacs JD, Cytokines in rheumatoid arthritis - shaping the immunological landscape. Nature reviews Rheumatology, 2016; 12(1): 63-68.

49. Mease PJ, Inhibition of interleukin-17, interleukin23 and the TH17 cell pathway in the treatment of psoriatic arthritis and psoriasis. Current opinion in rheumatology, 2015; 27(2): 127-133.

50. Mellett M, Atzei P, Horgan A, Hams E, Floss T, Wurst W, Fallon PG, Moynagh PN, Orphan receptor IL-17RD tunes IL-17A signalling and is required for neutrophilia. Nature communications, 2012; 3:1-10.

51. Miao J, Geng J, Zhang K, Li X, Li Q, Li C, Zhu P, Frequencies of circulating IL-17-producing CD4+CD161 $+\mathrm{T}$ cells and CD4+CD161 $+\mathrm{T}$ cells correlate with disease activity in rheumatoid arthritis. Modern rheumatology, 2013: 1-8.

52. Nemeth ZH, Bogdanovski DA, Barratt-Stopper P, Paglinco SR, Antonioli L, Rolandelli RH, Crohn's disease and ulcerative colitis show unique cytokine profiles. Cureus, 2017; 9(4): 1-11.

53. Ouyang W, Kolls JK, Zheng Y, The biological functions of $\mathrm{T}$ helper 17 cell effector cytokines in inflammation. Immunity, 2008; 28(4): 454-467.

54. Park JK, Han BK, Park JA, Woo YJ, Kim SY, Lee EY, Lee EB, Chalan P, Boots AM, Song YW, CD70-expressing CD4 $\mathrm{T}$ cells produce IFN-gamma and IL-17 in rheumatoid arthritis. Rheumatology, 2014; 53(10): 1896-1900.

55. Park JS, Park MK, Lee SY, Oh HJ, Lim MA, Cho WT, Kim EK, Ju JH, Park YW, Park SH, TWEAK promotes the production of Interleukin-17 in 
FARMACIA, 2018, Vol. 66, 3

rheumatoid arthritis. Cytokine, 2012; 60(1): 143149.

56. Paulissen SM, van Hamburg JP, Dankers W, Lubberts E, The role and modulation of CCR6+ Th17 cell populations in rheumatoid arthritis. Cytokine, 2015; 74(1): 43-53.

57. Pavelka K, Chon Y, Newmark R, Lin SL, Baumgartner S, Erondu N, A study to evaluate the safety, tolerability, and efficacy of brodalumab in subjects with rheumatoid arthritis and an inadequate response to methotrexate. Journal of rheumatology, 2015; 42(6): 912-919.

58. Pavlovic V, Dimic A, Milenkovic S, Krtinic D: Serum levels of IL-17, IL-4, and INFgamma in Serbian patients with early rheumatoid arthritis. JRMS, 2014; 19(1): 18-22.

59. Qian Y, Liu C, Hartupee J, Altuntas CZ, Gulen MF, Jane-Wit D, Xiao J, Lu Y, Giltiay N, Liu J, The adaptor Act1 is required for interleukin 17-dependent signaling associated with autoimmune and inflammatory disease. Nature immunology, 2007; 8(3): 247-256.

60. Roeleveld DM, Koenders MI, The role of the Th17 cytokines IL-17 and IL-22 in rheumatoid arthritis pathogenesis and developments in cytokine immunotherapy. Cytokine, 2015; 74(1): 101-107.

61. Rouvier E, Luciani MF, Mattei MG, Denizot F, Golstein P, CTLA-8, cloned from an activated T cell, bearing AU-rich messenger RNA instability sequences, and homologous to a herpesvirus saimiri gene. Journal of immunology, 1993; 150(12): 54455456.

62. Ruddy MJ, Wong GC, Liu XK, Yamamoto H, Kasayama S, Kirkwood KL, Gaffen SL, Functional cooperation between interleukin-17 and tumor necrosis factor-alpha is mediated by CCAAT/enhancerbinding protein family members. The Journal of biological chemistry, 2004; 279(4): 2559-2567.

63. Schiotis RE, Goșa D, Bocşan C, Suciu S, Buzoianu $\mathrm{AD}$, Particularities of treatment with conventional synthetic disease-modifying antirheumatic drugs (DMARDs) in a group of patients with rheumatoid arthritis. Farmacia, 2017; 65(2): 479-484.

64. Sato K, Suematsu A, Okamoto K, Yamaguchi A, Morishita Y, Kadono Y, Tanaka S, Kodama T, Akira S, Iwakura Y, Th17 functions as an osteoclastogenic helper $\mathrm{T}$ cell subset that links $\mathrm{T}$ cell activation and bone destruction. Journal of experimental medicine, 2006; 203(12): 2673-2682.

65. Schlegel PM, Steiert I, Kotter I, Muller CA, B cells contribute to heterogeneity of IL-17 producing cells in rheumatoid arthritis and healthy controls. PloS one, 2013; 8(12): 1-11.

66. Schminke B, Trautmann S, Mai B, Miosge N, Blaschke S, Interleukin 17 inhibits progenitor cells in rheumatoid arthritis cartilage. European journal of immunology, 2016; 46(2): 440-445.

67. Shen L, Zhang H, Yan T, Zhou G, Liu R: Association between interleukin 17A polymorphisms and susceptibility to rheumatoid arthritis in a Chinese population. Gene, 2015; 566(1): 18-22.

68. Smith JA, Colbert RA, Review: The interleukin-23/ interleukin-17 axis in spondyloarthritis pathogenesis: Th17 and beyond. Arthritis \& rheumatology, 2014; 66(2): 231-241.

69. Stamp LK, Cleland LG, James MJ, Upregulation of synoviocyte COX-2 through interactions with $\mathrm{T}$ lymphocytes: role of interleukin 17 and tumor necrosis factor-alpha. The Journal of rheumatology, 2004; 31(7): 1246-1254.

70. Stamp LK, James MJ, Cleland LG, Paracrine upregulation of monocyte cyclooxygenase- 2 by mediators produced by $\mathrm{T}$ lymphocytes: role of interleukin 17 and interferon-gamma. The Journal of rheumatology, 2004; 31(7): 1255-1264.

71. Strand V, Kosinski M, Gnanasakthy A, Mallya U, Mpofu S, Secukinumab treatment in rheumatoid arthritis is associated with incremental benefit in the clinical outcomes and HRQoL improvements that exceed minimally important thresholds. Health and quality of life outcomes, 2014; 12: 1-10.

72. Sun D, Novotny M, Bulek K, Liu C, Li X, Hamilton T, Treatment with IL-17 prolongs the half-life of chemokine CXCL1 mRNA via the adaptor TRAF5 and the splicing-regulatory factor SF2 (ASF). Nature immunology, 2011; 12(9): 853-860.

73. Tlustochowicz W, Rahman P, Seriolo B, Krammer G, Porter B, Widmer A, Richards HB, Efficacy and safety of subcutaneous and intravenous loading dose regimens of secukinumab in patients with active rheumatoid arthritis: results from a randomized phase II study. The Journal of rheumatology, 2016; 43(3): 495-503.

74. van Hamburg JP, Asmawidjaja PS, Davelaar N, Mus AM, Colin EM, Hazes JM, Dolhain RJ, Lubberts E, Th17 cells, but not Th1 cells, from patients with early rheumatoid arthritis are potent inducers of matrix metalloproteinases and proinflammatory cytokines upon synovial fibroblast interaction, including autocrine interleukin-17A production. Arthritis and rheumatism, 2011; 63(1): 73-83.

75. Xie Q, Wang SC, Li J, IL-17: a potential therapeutic target for rheumatoid arthritis?. Clinical rheumatology, 2012; 31(7): 1145-1146.

76. Yao C, Sakata D, Esaki Y, Li Y, Matsuoka T, Kuroiwa K, Sugimoto Y, Narumiya S, Prostaglandin E2-EP4 signaling promotes immune inflammation through Th1 cell differentiation and Th17 cell expansion. Nature medicine, 2009; 15(6): 633-640.

77. Zhu S, Pan W, Song X, Liu Y, Shao X, Tang Y, Liang D, He D, Wang H, Liu W, The microRNA miR-23b suppresses IL-17-associated autoimmune inflammation by targeting TAB2, TAB3 and IKKalpha. Nature medicine, 2012; 18(7): 1077-1086.

78. Zhu S, Qian Y, IL-17/IL-17 receptor system in autoimmune disease: mechanisms and therapeutic potential. Clinical science, 2012; 122(11): 487-511. 